\title{
Contraception for the Cardiac Patient: a Cardiologist's Primer
}

Karen L. Florio, $D \mathrm{O}^{1,2,{ }^{*}} \oplus$

Monica Kao, MD MPH

Traci Johnson, $M D^{2}$

Heidi A. Tuttle, PharmD CDCES ${ }^{3}$

Darcy White, $R N^{1}$

Lynne Nelson, WHNP ${ }^{1}$

Neil Patel, $M D^{2}$

Devon Ramaeker, $M D^{1}$

Sue Kendig, JD, BC-WHNP

Laura Schmidt, $M D^{2,4}$

Anna Grodzinsky, MD, MSc ${ }^{2,4}$

Katherine Economy, $M D^{6}$

\author{
Address \\ ${ }^{*}{ }^{1}$ Heart Disease in Pregnancy Program, Saint Luke's Hospital of Kansas City, \\ Kansas City, M0, 64111, USA \\ Email: Kflorio@saintlukeskc.org \\ ${ }^{2}$ University of Missouri-Kansas City School of Medicine, Kansas City, MO, USA \\ ${ }^{3}$ Kansas City, MO, USA \\ ${ }^{4}$ Saint Luke's Mid-America Heart Institute, Kansas City, MO, USA \\ ${ }^{5}$ SSM Health Saint Louis University Hospital, St. Louis, MO, USA \\ ${ }^{6}$ Brigham and Women's Hospital, Harvard Medical School, Boston, MA, USA
}

Published online: 9 November 2020

(C) The Author(s) 2020

This article is part of the Topical Collection on Pregnancy and Cardiovascular Disease

Keywords Contraception · Cardio-obstetrics · Cardiovascular disease · Long-acting contraception (LARC) • Birth control

\begin{abstract}
Purpose of review Cardiovascular disease (CVD) is the number one cause of maternal mortality in the USA. There are many cardiac conditions which pose significant risk to maternal health, and these women should be offered options to avoid unwanted pregnancies. Individualized contraceptive counseling focusing on woman's desire for future pregnancy, comorbid conditions, and desire for hormone or non-hormonal (contraceptive) options is paramount to avoid adverse or unwanted side effects. The purpose of this review is to give general guidance on prescribing both hormonal and non-hormonal contraceptives for providers caring for women with heart disease.
\end{abstract}


Recent findings Specific recommendation for the use of either non-hormonal or hormonal contraception requires knowledge of the types of contraceptive options available, cost, failure rates, and contraindications to use. Newer progestin-only options have become available and should be considered first-line therapy for women with cardiovascular disease.

Summary The physiologic burden of pregnancy on the cardiovascular system can cause significant maternal morbidity and mortality for women with underlying CVD. These women should be offered safe and effective options for birth control, and both cardiology and obstetrical providers alike should possess fundamental knowledge of appropriate options.

\section{Introduction}

The maternal mortality rate (MMR) in the USA stands at 16.9 per 100,000 and is higher than that of any other industrialized nation [1]. In response to this alarming trend, two-thirds of states have established maternal mortality review committees. Childbirth is the sixth highest cause of mortality in women ages 20-34 [2]. Of these childbirth-related deaths, cardiovascular disease has been found to be the leading cause [2,3]. Advances in cardiovascular treatment and surgery have enabled children born with congenital cardiac anomalies to survive into adulthood, with many of these women desiring fertility. Delayed childbearing, coupled with rising rates of diabetes, obesity, and other traditional cardiovascular risk factors, have also contributed to the growing trend of maternal deaths. Optimizing medical comorbidities and cardiovascular care prior to pregnancy is essential, and this responsibility falls upon both the obstetrician and the cardiologist alike. In order to reduce the burden of unintended pregnancies and optimize timing of pregnancy for women with heart disease, providers who care for these women must have knowledge of safe and effective contraceptive options.

Both over-the-counter and prescription contraceptive methods are widely available in the USA to assist women in preventing unwanted or unintended pregnancies. The benefits of family planning are vast, including fewer teen pregnancies, fewer abortions, higher educational attainment rates, lower incidence of sexually transmitted diseases, lower preterm birth rates, reduction in maternal morbidity, reduction in neonatal and maternal mortality, and greater economic growth [4-6]. More than 99\% of American women aged 15-44 report having used some method of birth control at some point during their reproductive lives [7]. However, lack of knowledge regarding available options and correct use, misperceptions and exaggerated concerns about safety, restrictions barring minors from consenting to contraceptive services, limited insurance coverage, and cost continue to pose major barriers to women in obtaining effective contraception [8].

Choosing a particular contraceptive method is a highly individualized decision; each woman should retain autonomy and the ability to choose a method that is compatible with her personal values, level of comfort, reproductive desires, and underlying medical issues. There are both barrier and hormonal forms of pregnancy prevention, and each comes with its unique risk and benefit profile. Methods differ in terms of effectiveness, side effect profile, drug interactions, use of hormones, cost, confidentiality concerns, and the degree of control women have over their use.

\section{Cardiologists as women's reproductive health providers}

The ever-changing climate of medicine has altered and expanded the physician role into new arenas. For example, as obstetricians are stepping into new positions as mental healthcare providers, so too are cardiologists expected to 
have a breadth of knowledge regarding contraception and contraceptive counseling. Ideally, this counseling would be performed jointly by an experienced cardiologist and obstetrician. However, many facilities do not have the capability of maintaining a joint cardio-obstetrics clinic. Women with underlying cardiovascular disease often view their cardiologist as being their primary care provider, and this touch point may be the only opportunity to discuss family planning topics. As well, many young women with congenital heart disease do not enter into gynecologic care until early adulthood and therefore may go without contraceptive counseling until that time. Adolescence is an optimal time to initiate the discussion surrounding contraception, as only onequarter of teens engaging in sexual behavior are reported to utilize any form of protection against sexually transmitted diseases or pregnancy [9]. Without contraception, up to $85 \%$ of women will experience an unintended pregnancy within a year [10]. As the sole healthcare provider to many adolescents with heart disease, cardiologists should view each visit as an opportunity to discuss family planning issues. This will require a familiarity with the different types of available contraceptive options, their risk and safety profiles, efficacy rates, and any contraindications to use, particularly in cardiac disease states. The aim of this review is to provide a quick reference to enhance cardiologists' comfort level in discussing family planning and contraceptive options in women with cardiovascular disease.

\section{Metabolism and side effects of hormonal contraceptives}

As with many steroids, estrogen and progesterone exert various metabolic effects throughout the body. Their directional effect on lipid profiles, hemostatic variables, and even carbohydrate metabolism is dependent upon the route of administration, dosage, and type of hormone (Fig. 1). Metabolism of the various exogenous estrogens is similar to endogenous estradiol in that they undergo extensive first-pass metabolism in the cytochrome P450 CYP3A system, leading to the formation of several active metabolites. Over $95 \%$ of orally administered estrogen is metabolized by the enterohepatic system prior to reaching systemic circulation. Concentration can be affected by other medications including St. John's Wort, many antiepileptics, benzodiazepines, bosentan, and warfarin $[11,12]$. Estrogens are known to increase blood pressure, promote fluid retention through stimulated hepatic synthesis of angiotensin leading to increased aldosterone levels, increase VLDL and HDL, decrease LDL, increase levels of sex hormone binding globulin, and increase liver proteins leading to changes in the procoagulation/fibrinolytic balance [12-16]. As such, exogenous or synthetic estrogen has been associated with an increase in ischemic stroke, myocardial infarction, venous thromboembolism, and a lengthening in the QT interval [17-20]. The risk for a thrombotic event rises with increasing estrogen doses, varies by the type of progestin (highest with the 3rd and 4th generation), and is highest for the first 3 months of use $[18,21]$.

Unlike estrogens, progestins have differing first-pass metabolism rates. Progestin-only contraception does not seem to have the same negative effects on the coagulation cascade as estrogen or combined formulations and therefore can be used in women with higher risks for cardiovascular or thrombotic events $[10,22]$. The first- and second-generation progestins (norethindrone and 


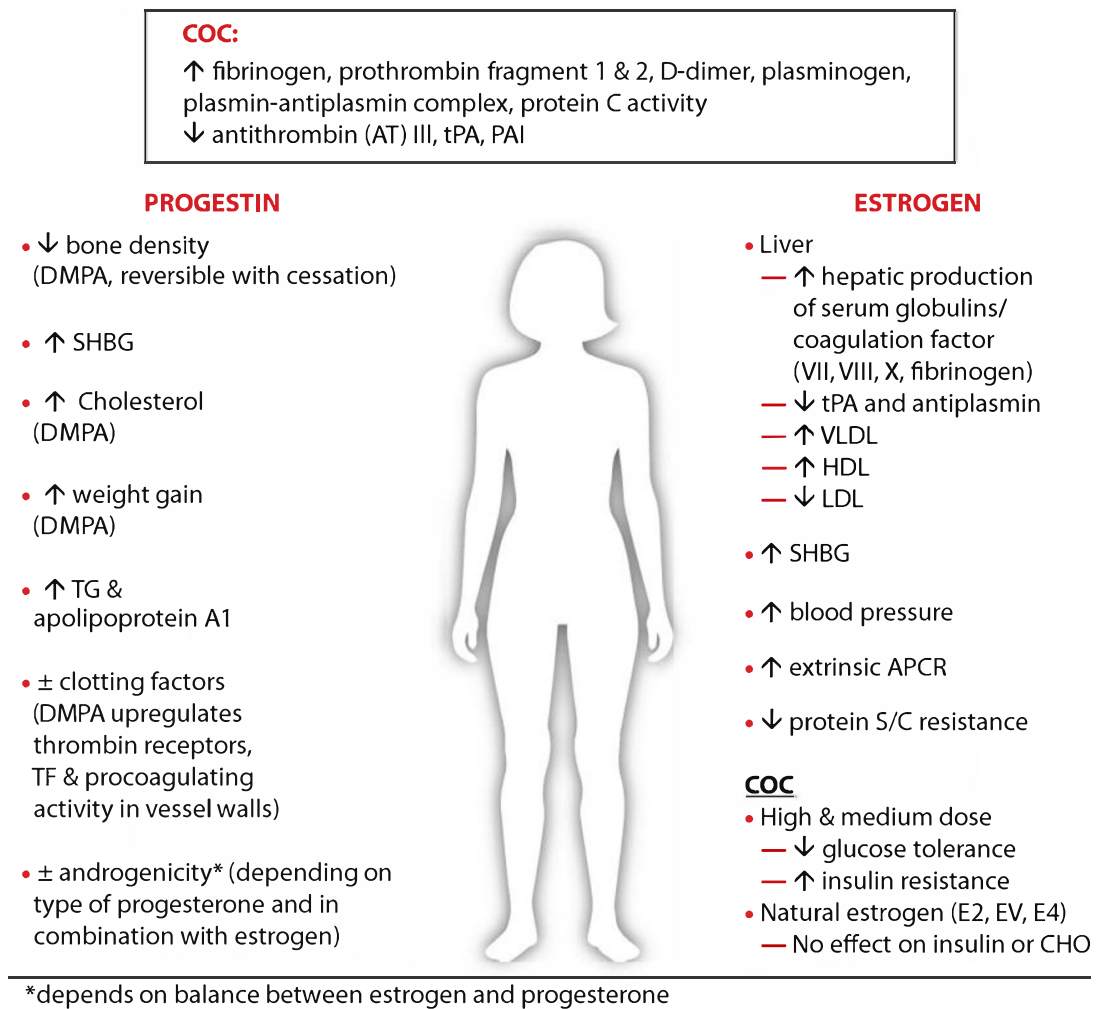

Fig. 1. Metabolic effects of hormonal contraception. DMPA, depomedroxyprogesterone acetate; SHBG, serum hormone-binding globulin; TG, triglycerides; MPA, medroxyprogesterone acetate; TF, tissue factor; tPA, tissue plasminogen activator; VLDL, very low density lipoprotein; HDL, high density lipoprotein; LDL, low density lipoprotein; APCR, activated protein C resistance; E2, estradiol; $\mathrm{EV}$, estradiol valerate; E4, estetrol; $\mathrm{CH}$, carbohydrates; $\mathrm{CHC}$, combined hormonal contraceptives; PAI, plasminogen activator inhibitor.

levonorgestrel) are estrane derivatives of testosterone with a higher rate of androgenic side effects and thus are more likely to cause bloating, fluid retention, lowering of HDL, and acne than the third- and fourth-generation medications [23].

\section{Types of contraceptive methods and efficacy}

The WHO and the US Medical Eligibility Criteria for Contraceptive Use (USMEC) are classification guidelines developed to guide contraceptive management in women with comorbidities. Although the USMEC (Table 1) gives guidance for women with cardiovascular disease, it does not distinguish between women solely with cardiovascular disease from those with multiple comorbidities. However, the WHO guidelines encompass cardiac disease with other comorbid conditions. Both guidelines can be utilized when deciding upon the safest and most efficacious contraceptive method in a woman with multiple comorbidities. All possible contraceptive options must be weighed against the risk of pregnancy, and the appropriate type of contraception should be implemented so as to prevent or mitigate any future pregnancy-associated complications. 


\section{Table 1. United States Medical Eligibility Criteria (MEC) for Contraceptive Use}

$1=\mathrm{A}$ condition for which there is no restriction for the use of the contraceptive method

2 = A condition for which the advantages of using the method generally outweigh the theoretical or proven risks

$3=$ A condition for which the theoretical or proven risks usually outweigh the advantages of using the method

$4=\mathrm{A}$ condition that represents an unacceptable health risk if the contraceptive method is used

Contraceptives are classified on the basis of those that contain exogenous hormones and those that do not, the latter of which may act either as a barrier to sperm entry or inhibit sperm activity/viability. Within the class of hormonal contraceptives, there are two main types: those that contain a combination of estrogen and progestin and those with progestin alone (Table 2). The most commonly used form of estrogen is ethinyl estradiol (EE), which was the first formulation used when the pill was introduced to the market in 1960. Only recently have three new estrogen formulations been developed to further alter the metabolic side effects mentioned above. There are four generations of progestins, each one with progressively fewer androgenic properties [23-26]. This is important to consider when prescribing first- and second-generation progestin-containing hormonal contraceptives, as the adverse effects may include higher risk of $\mathrm{CV}$ morbidity [23]. In this case, it may be more appropriate to choose a third- or fourth-generation progestin with less androgenic side effects or even those that have partial anti-androgenic and antimineralocorticoid activity. The following section delineates the types of contraceptive options by their mechanism of action, effectiveness, and safety in women with heart disease.

\section{Most effective, with fewest contraindications: intrauterine devices, implants, and sterilization}

The long-acting reversible contraceptive methods (IUDs and progesterone implants) or LARCs are the most effective at pregnancy prevention [27]. There are five different types of intrauterine devices on the market in the USA, four of which are progesterone-containing devices and one containing copper. The 4 progesterone-containing IUDs differ according to their physical size, length of suggested use, and the amount of progestin released daily. All are T-shaped devices with various levels of progestin (Mirena LNG-20, Liletta LNG-18.6, Kyleena LNG-19.5, and Skyla LNG-13.5) contained in a polydimethylsilicone sleeve and release a set amount of hormone daily. Depending on the brand, these forms of contraception can be left in place for up to 5 years (Mirena ${ }^{\circledR}$ 5 years, Liletta ${ }^{\circledR} 4$ years, Kyleena ${ }^{\circledR} 5$ years, and Skyla ${ }^{\circledR} 3$ years) $[27,28]$. Within the first year of use, the progestin-containing IUDs have a higher efficacy rate than female sterilization $[28,29]$. The failure rate decreases only slightly with prolonged use to $0.2 \%$ [28]. The primary mechanism of action prevents fertilization by causing a change in the amount and viscosity of the cervical mucus, inhibiting sperm entry into the uterine cavity. Progestin-containing IUDs also act on the uterine lining to induce decidualization (thinning of the endometrial lining) and atrophy. Finally, at higher doses and during the first few months of use, the progestin effect also inhibits ovulation [30-33]. For the non-hormonal 
copper IUD (ParaGard ${ }^{\circledR}$ ), the mechanism of action results from an increase in copper ions, enzymes, prostaglandins, and macrophages that impair sperm function and thereby inhibit fertilization [34,35]. The copper T380A IUD is approved for use for up to 10 years and may also be used for emergency contraception if placed up to 7 days after unprotected intercourse [36].

There are numerous other advantages to the various types of LARC. The progestin-containing IUDs decrease heavy menstrual bleeding by up to $98 \%$ and cause complete cessation of menses in up to $44 \%$ of users after 6 months of use [31,37]. This is ideal for women who experience heavy menstrual cycles resulting in anemia and/or those on anticoagulation. Progestin-containing IUDs are also approved for the treatment of dysmenorrhea, endometriosis, and adenomyosis and have been shown to decrease the incidence of endometrial polyps and both endometrial and ovarian cancers $[37,38]$. These cancer preventative effects even extend to the copper IUD with a yet unknown mechanism of action [37]. The typical and perfect use rates are similar as this type of contraception is user-independent [27]. Multiple studies have found that the progestin-containing IUDs and copper IUD have similar efficacy and safety profiles in both adults and adolescents [39]. Therefore, IUDs should be considered first-line contraceptive therapy not only for adult women with cardiovascular risk factors but also for adolescents with congenital cardiac disease.

The most common side effects for the progestin-containing IUD include pain at the time of insertion, irregular and/or intermenstrual bleeding, and hormone-related menstrual symptoms such as breast tenderness, headaches, and acne [31]. There are some randomized controlled trials reporting decreased pain and easier insertion with the use of misoprostol placed the night prior to the procedure [40]. The copper IUD has a higher rate of dysmenorrhea and heavy menstrual bleeding and therefore should not be considered in women on anticoagulation as the rates of blood loss can increase by up to $65 \%[31,41]$. Uterine perforation at the time of placement is uncommon (1 per 1000 placements) but can result in migration of the IUD into surrounding structures and subsequent surgery to remove the device $[42,43]$. Expulsion after placement occurs at a rate of 2 to $10 \%$ and is more common in the first 3 months of use, which puts women unknowingly at risk for unintended pregnancies [27,31]. Although current guidelines do not recommend antibiotic prophylaxis prior to IUD insertion for high-risk cardiac patients, there is a slight increased risk of pelvic inflammatory infection within the first month of use and has been associated with endocarditis in case reports of women with congenital heart disease [44,45]. It is the opinion of these authors that pre-procedural antibiotics may be considered for women in whom the associated morbidity of infective endocarditis is unacceptably high compared to the risks of antibiotic use.

Manipulation of the cervix can result in a vagal reaction in 5\% of women, and in patients with a fixed cardiac output or decreased ventricular function, this can be life-threatening. For those women who risk cardiovascular collapse due to a vasovagal reaction (i.e., Fontan circulation, severe aortic stenosis, Eisenmenger's, severe left ventricular dysfunction) with IUD insertion, the etonogestrel subdermal implant is a safe and highly effective progestin-only alternative that is approved for use up to 3 years. It is a single-rod implant that contains $68 \mathrm{mg}$ of the progestin etonogestrel and $15 \mathrm{mg}$ of barium sulfate so as to be identified on X-ray or ultrasound. A trained clinician is required for insertion into the medial aspect of the proximal arm which may limit 


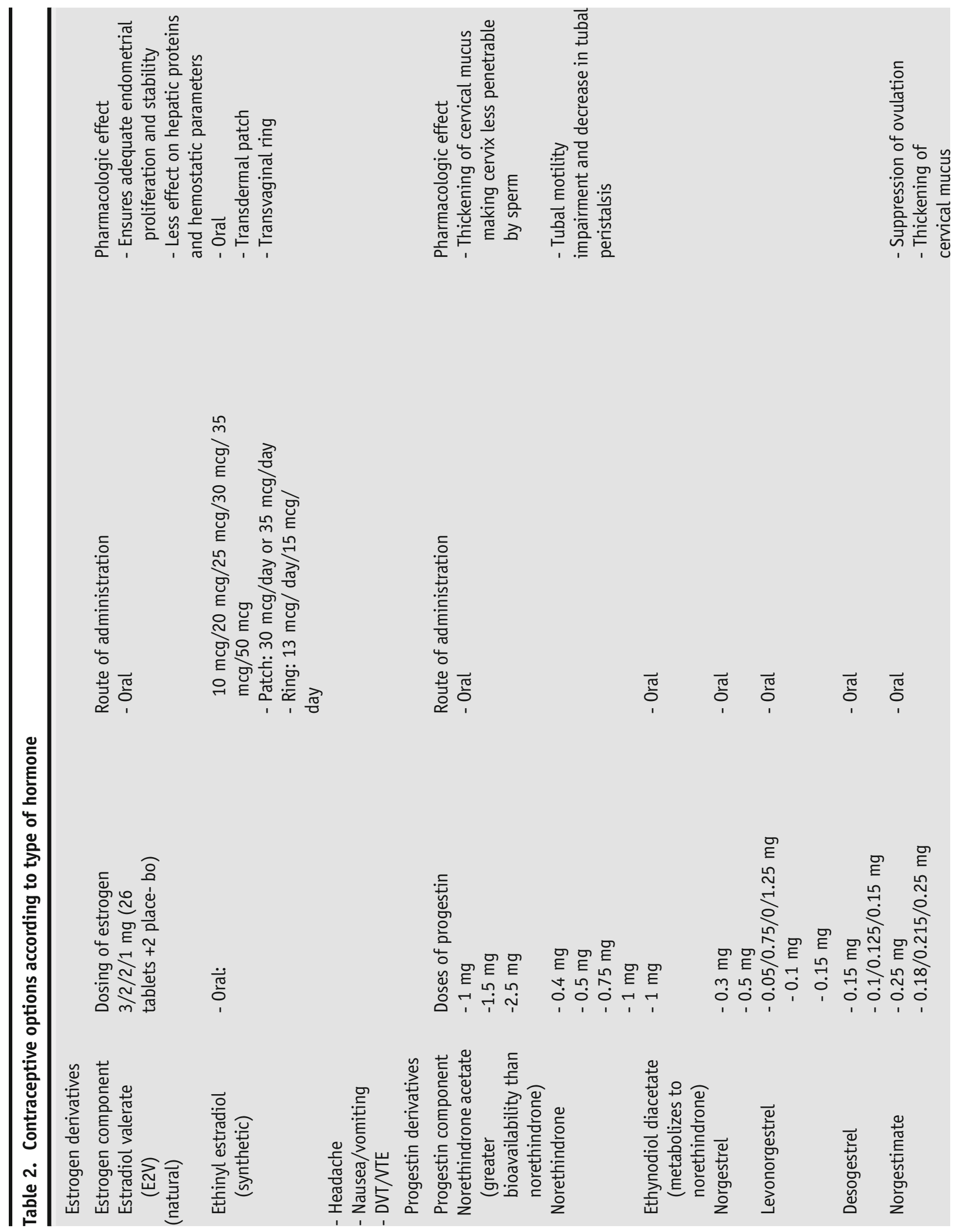



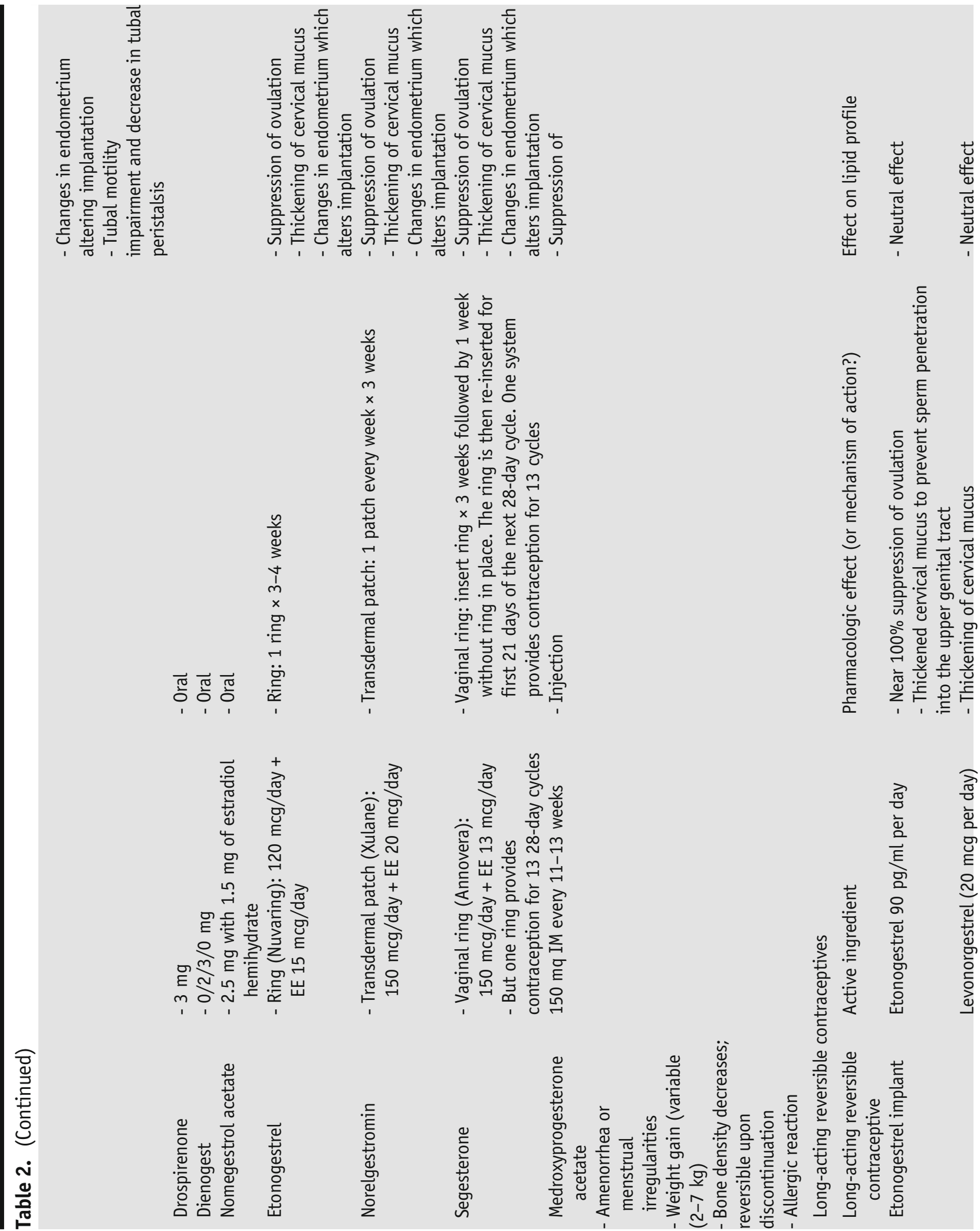


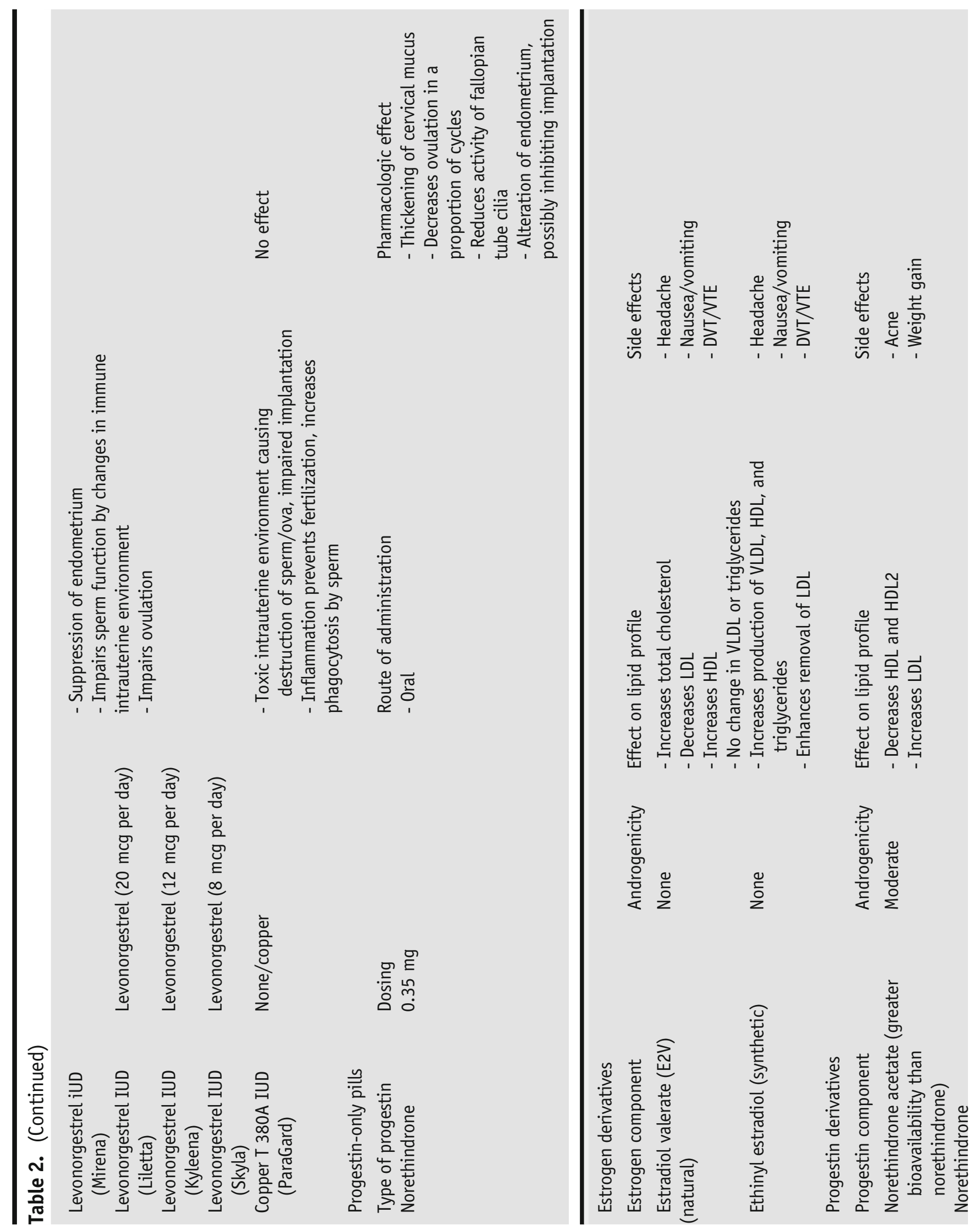




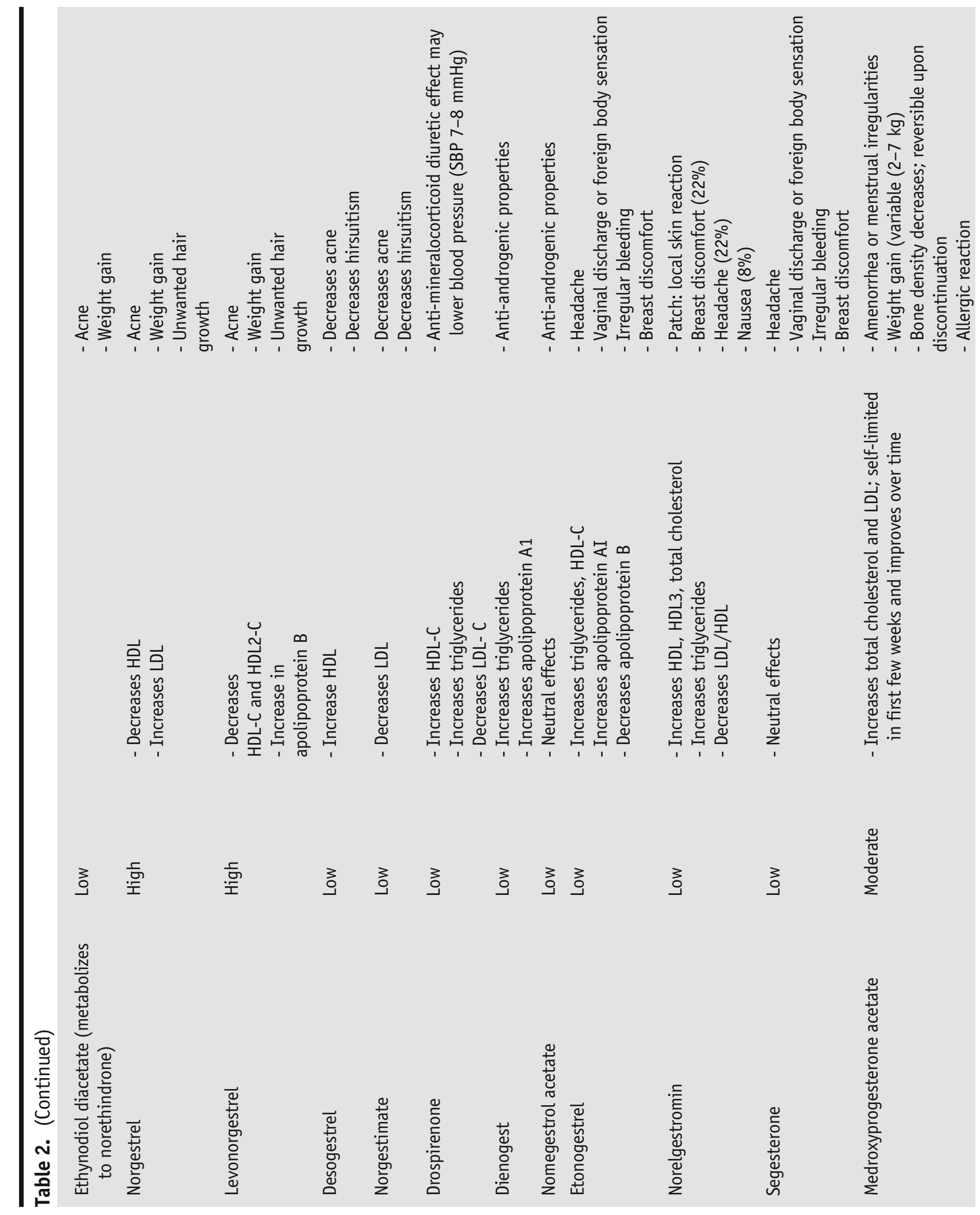



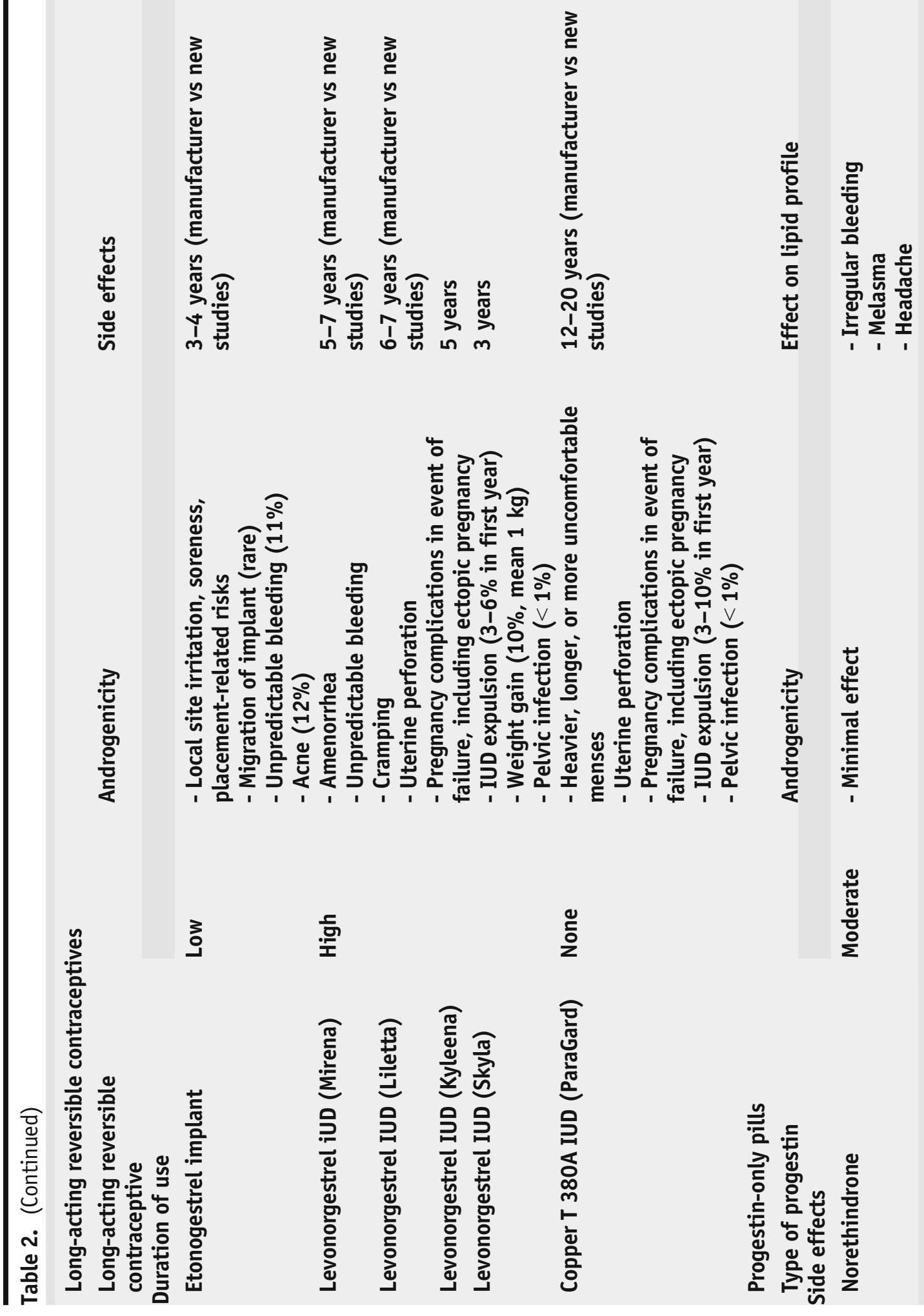
accessibility. The primary mechanism of action is to inhibit ovulation. Similar to the progestin-containing IUD, it also thins the endometrial lining and thickens the cervical mucus $[30,46]$. The etonogestrel implant has an extremely low failure rate, comparable to that for permanent sterilization [28]. It is an excellent choice for adolescent females, as uptake and continuation rates are high [47]. Side effects are again similar to the LNG IUD, with most commonly reported side effects being headache, weight gain, acne, and emotional lability [48]. It is an alternative option to the LNG IUD, and a choice for women who are on anticoagulation as amenorrhea occurs in 22 to $29 \%$ of users $[49,50]$. However, up to $20 \%$ also experience irregular and/or intermenstrual bleeding, and this should be taken into consideration when deciding between the two forms of contraception [51]. Other non-cardiac contraindications include current or recent history of breast cancer, severe decompensated liver cirrhosis, hepatocellular carcinoma, and unexplained vaginal bleeding prior to investigation $[10,22]$. There is no permanent effect on bone mineral density, and the risk of venous thromboembolism, myocardial infarction, or stroke is not increased compared to non-users $[18,35]$. The efficacy remains high even in women in higher BMI categories [31].

Female sterilization is an option for women who have completed childbearing or in those for whom pregnancy presents an unacceptably high risk. This can be achieved either via laparoscopy, through an open abdominal incision, or at the time of cesarean delivery. The risk of failure with sterilization is dependent upon the technique, approach, and age of the patient, with an overall quoted efficacy of $>99.5 \%[10,52-55]$.

Moderately effective with moderate contraindications: depot medroxyprogesterone acetate injection, combined hormonal contraceptive pills, and progestin-only pills

Depot medroxyprogesterone acetate or DMPA is an injectable form of progestinonly contraception that is highly effective and with minimal contraindications. It is an optimal choice for women with heavy menstrual bleeding, hepatic disease, or any other contraindication to the estrogen component of CHCs [37]. It is administered intramuscularly at a dose of $150 \mathrm{mg} / \mathrm{dL}$ and given at 3-month intervals. Its long-acting efficacy is a direct effect of the pharmacologically active drug that can persist in the tissue for long periods of time [32]. The failure rates are similar to the previously mentioned LARCs at $0.2 \%[10,22]$. The higher failure rate is likely due to non-compliance of returning for repeat injections and can be as high as 44$68 \%$ in some users $[32,56]$. The mechanism of action is similar to all other forms of systemic progesterone in that it inhibits ovulation and causes atrophy of the uterine lining. Added benefits of this form of contraception include amenorrhea and endometrial protection. Other side effects include irregular bleeding, weight gain, and delayed return of fertility $[32,57,58]$. There is transient but decreased bone density in women with prolonged use, alteration in lipid profiles (increased cholesterol and triglycerides with concomitant decrease in HDL), and slightly increased risk for a venous thromboembolic events [58-60].

The progestin-only pill, alternatively known as the "mini-pill," contains $0.35 \mathrm{mg}$ of the progestin norethindrone and can be offered as an alternative oral contraceptive option when estrogen is contraindicated. The mechanism of action and side effect profile is similar to all the progestins; however, the failure rate of this type of contraception is reported between 9 and $15 \%$ as its 
gonadotropin-inhibitory effect relies on perfect compliance and has to be taken at the same time every day $[22,61,62]$.

Combined hormonal contraceptives (CHC) include any oral, vaginal, or transdermal form that contains both an estrogen and progestin component. Overall efficacy is from suppression of follicle-stimulating hormone (FSH), suppression of luteinizing hormone (LH) and the LH surge that triggers ovulation, alteration in the cervical mucus, and decidualization of the endometrium [33]. There are various formulations of both the estrogen and progestin components that will lead to desired and undesired (side) effects. Failure rates of $0.3 \%$ with perfect use and $9 \%$ with typical use have been documented, again largely due to the user-dependent requirement of timely daily dosing [63]. CHCs carry side effects that may render them inappropriate choices for women with cardiovascular disease. Estrogen has been known to raise blood pressure and should be used with caution in patients with hypertension. Although the pharmacokinetic effects of estrogen suggest an increase in fluid retention, the effects are likely of minimal clinical significance and should not preclude use in women with cardiovascular disease as the sole contraindication. More importantly, multiple studies have found a threefold increase in ischemic stroke, fivefold increase in myocardial infarction, and up to fourfold increase in VTE. These risks increase with increasing doses of estrogen [35,64-66]. The progestin component (gestogene, desogestrel, cyproterone acetate, and drospirenonecontaining combination contraceptives) when combined with estrogen may independently increase the risk of VTE; however, when used without estrogen, this does not increase the risk of VTE above baseline [67]. The concomitant use of cardiac medications such as warfarin or bosentan must be considered when choosing contraception, as these interact with the CYP3A4 system and can decrease the efficacy of $\mathrm{CHC}$ as mentioned above. In women with underlying cardiovascular risk factors, alternative forms to $\mathrm{CHC}$ should be considered.

Least efficacious, minimal to no contraindications: barrier methods, spermicide, and natural family planning

Examples of these methods include condoms, spermicides, female sponges, female diaphragms, female condoms, and cervical caps. These methods are associated with the highest failure rates and account for up to $5 \%$ of all unplanned pregnancies. These should be a last resort as far as contraceptive options in women with cardiovascular disease. The efficacy is dependent upon perfect use and with some forms, proper fitting performed by a gynecologist.

\section{Emergency contraception}

In all women, but particularly those in whom pregnancy poses an unacceptably high risk of adverse outcomes, emergency contraception should be discussed at every visit. There are several different forms of emergency contraception, but the most effective is placement of a copper IUD. If inserted within 7 days of unprotected intercourse, the risk of pregnancy is reduced by more than $99 \%$ [22]. It is important to counsel the patient on the currently available products on the market (Table 3 from Lee et al.), timing of intended use following unprotected intercourse, most common side effects, efficacy in larger BMI status, safety profile during breastfeeding (for those in the postpartum period), 


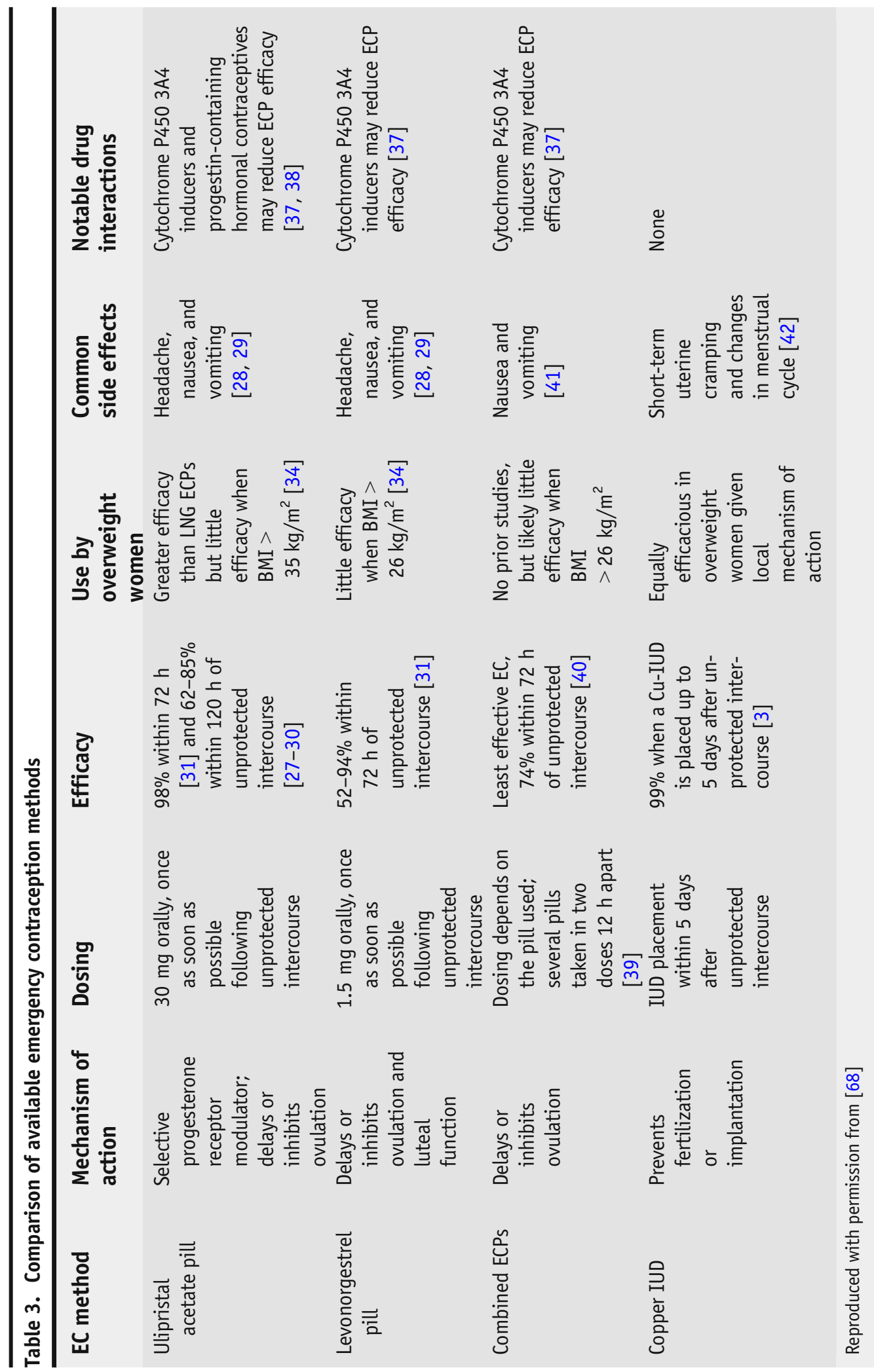




\section{Summary}

and the rapidity of fertility resumption $[68,69]$. Furthermore, these products are not abortifacients and should not be used outside the recommended exposure window. There are currently no cardiac conditions for which the risks of use of emergency contraception outweigh potential benefit [22].

There are numerous contraceptive options available to women with cardiovascular disease. The personalization of birth control to patients' cardiovascular conditions remains key and should be the most important consideration when prescribing contraception. The nuances of timing, efficacy, duration of use, and side effects will also influence decision-making in this complex group of women.

\section{Compliance with Ethical Standards}

\section{Conflict of Interest}

Karen L. Florio declares that she has no conflict of interest. Monica Kao declares that she has no conflict of interest. Traci Johnson declares that she has no conflict of interest. Heidi A. Tuttle declares that she has no conflict of interest. Darcy White declares that she has no conflict of interest. Lynne Nelson declares that she has no conflict of interest. Neil Patel declares that he has no conflict of interest. Devon Ramaeker declares that he/she has no conflict of interest. Sue Kendig declares that he/she has no conflict of interest. Laura Schmidt declares that she has no conflict of interest. Anna Grodzinsky declares that she has no conflict of interest. Katherine Economy declares that she has no conflict of interest.

\section{Human and Animal Rights and Informed Consent Statement}

This article does not contain any studies with human or animal subjects performed by any of the authors.

\section{Open Access}

This article is licensed under a Creative Commons Attribution 4.0 International License, which permits use, sharing, adaptation, distribution and reproduction in any medium or format, as long as you give appropriate credit to the original author(s) and the source, provide a link to the Creative Commons licence, and indicate if changes were made. The images or other third party material in this article are included in the article's Creative Commons licence, unless indicated otherwise in a credit line to the material. If material is not included in the article's Creative Commons licence and your intended use is not permitted by statutory regulation or exceeds the permitted use, you will need to obtain permission directly from the copyright holder. To view a copy of this licence, visit http://creativecommons.org/licenses/by/4.0/.

\section{References and Recommended Reading}

1. Pregnancy Mortality Surveillance System; 2019. Accessed December 23, 1029. https://www.cdc.gov/ reproductivehealth/maternal-mortality/pregnancymortality-surveillance-system.htm.

2. Collier A-RY, Molina RL. Maternal mortality in the United States: updates on trends, causes, and solutions.
NeoReviews. 2019;20(10):e561-74. https://doi.org/ 10.1542/neo.20-10-e561.

3. Creanga AA. Maternal mortality in the United States: a review of contemporary data and their limitations. Clin Obstet Gynecol. 2018;61(2):296-306. https://doi.org/ 10.1097/GRF.0000000000000362. 
4. Tsui AO, McDonald-Mosley R, Burke AE. Family planning and the burden of unintended pregnancies. Epidemiol Rev. 2010;32(1):152-74. https://doi.org/ 10.1093/epirev/mxq012.

5. Secura GM, Madden T, McNicholas C, Mullersman J, Buckel CM, Zhao Q, et al. Provision of no-cost, longacting contraception and teenage pregnancy. $\mathrm{N}$ Engl J Med. 2014;371(14):1316-23. https://doi.org/10. 1056/NEJMoa1400506.

6. Sonfield A, Hasstedt K, Kavanaugh M, Anderson R. The social and economic benefits of women's ability to determine whether and when to have children. Guttmacher Institute; 2013. www.guttmacher.org/pubs/ social-economic-benefits.pdf. Accessed June 2020.

7. Fitrianto A. Family Planning/Contraception; 2018. https://www.who.int/newsroom/fact-sheets/detail/ family-planningcontraception. Accessed $26 \mathrm{Apr}$ 2020.

8. Committee on Health Care for Underserved Women. Committee opinion no. 615: Access to contraception. Obstet Gynecol. 2015;125(1):250-5. https://doi.org/ 10.1097/01.AOG.0000459866.14114.33.

9. Fry KM, Gerhardt CA, Ash J, Zaidi AN, Garg V, McBride $\mathrm{KL}$, et al. Lifetime prevalence of sexual intercourse and contraception use at last sex among adolescents and young adults with congenital heart disease. J Adolesc Health. 2015;56(4):396-401. https://doi.org/10. 1016/j.jadohealth.2014.12.013.

10. Gaffield ML, Kiarie J. WHO medical eligibility criteria update. Contraception. 2016;94(3):193-4. https://doi. org/10.1016/j.contraception.2016.07.001.

11. Cauldwell M, Steer P, Sterrenburg M, Wallace S, Malin G, Ulivi G, et al. Birth weight in pregnancies complicated by maternal heart disease. Heart.

2019;105(5):391-8. https://doi.org/10.1136/heartjnl2018-313551.

12. De Leo V, Musacchio MC, Cappelli V, Piomboni P, Morgante G. Hormonal contraceptives: pharmacology tailored to women's health. Hum Reprod Update. 2016;22(5):634-46. https://doi.org/10.1093/ humupd/dmw016.

13. Sitruk-Ware R, Nath A. Metabolic effects of contraceptive steroids. Rev Endocr Metab Disord. 2011;12(2):63-75. https://doi.org/10.1007/s11154011-9182-4.

14. Bastianelli C, Farris M, Rosato E, Brosens I, Benagiano G. Pharmacodynamics of combined estrogenprogestin oral contraceptives: 1. Effects on metabolism. Expert Rev Clin Pharmacol. 2017;10(3):315-26. https://doi.org/10.1080/17512433.2017.1271708.

15. Boldo A, White WB. Blood pressure effects of the oral contraceptive and postmenopausal hormone therapies. Endocrinol Metab Clin N Am. 2011;40(2):419_ 32.

ix. https://doi.org/10.1016/j.ecl.2011.01.008.

16. Christy NP, Shaver JC. Estrogens and the kidney. Kidney Int. 1974;6(5):366-76. https://doi.org/10.1038/ ki.1974.120.
17. Petitti DB, Sidney S, Bernstein A, Wolf S, Quesenberry C, Ziel HK. Stroke in users of low-dose oral contraceptives. N Engl J Med. 1996;335(1):8-15. https://doi.org/ 10.1056/NEJM199607043350102.

18. Lidegaard Ø, Løkkegaard E, Jensen A, Skovlund CW, Keiding N. Thrombotic stroke and myocardial infarction with hormonal contraception. N Engl J Med. 2012;366(24):2257-66. https://doi.org/10.1056/ NEJMoa1111840.

19. de Bastos M, Stegeman BH, Rosendaal FR, van Hylckama Vlieg A, Helmerhorst FM, Stijnen T, et al. Combined oral contraceptives: venous thrombosis. Cochrane Database Syst Rev. 2014;3:CD010813. https://doi.org/10.1002/14651858.CD010813.pub2.

20. Sedlak T, Shufelt C, Iribarren C, Lyon LL, Bairey Merz $\mathrm{CN}$. Oral contraceptive use and the ECG: evidence of an adverse QT effect on corrected QT interval. Ann Noninvasive Electrocardiol. 2013;18(4):389-98. https://doi.org/10.1111/anec. 12050.

21. Dinger J, Assmann A, Möhner S, Minh TD. Risk of venous thromboembolism and the use of dienogestand drospirenone-containing oral contraceptives: results from a German case-control study. J Fam Plann Reprod Health Care. 2010;36(3):123-9. https://doi. org/10.1783/147118910791749416.

22. Curtis KM, Tepper NK, Jatlaoui TC, et al. U.S. Medical Eligibility Criteria for Contraceptive Use, 2016. MMWR Recomm Rep. 2016;65(3):1-103. https://doi.org/10. 15585/mmwr.rr6503a1.

23. Lawrie TA, Helmerhorst FM, Maitra NK, Kulier R, Bloemenkamp K, Gülmezoglu AM. Types of progestogens in combined oral contraception: effectiveness and side-effects. Cochrane Database Syst Rev. 2011;5:CD004861. https://doi.org/10.1002/ 14651858.CD004861.pub2.

24. Grandi G, Cagnacci A, Volpe A. Pharmacokinetic evaluation of desogestrel as a female contraceptive. Expert Opin Drug Metab Toxicol. 2014;10(1):1-10. https:// doi.org/10.1517/17425255.2013.844229.

25. Giribela CRG, Consolim-Colombo FM, Nisenbaum MG, Moraes TL, Giribela AHG, Baracat EC, et al. Effects of a combined oral contraceptive containing $20 \mathrm{mcg}$ of ethinylestradiol and $3 \mathrm{mg}$ of drospirenone on the blood pressure, renin-angiotensin-aldosterone system, insulin resistance, and androgenic profile of healthy young women. Gynecol Endocrinol. 2015;31(11):912-5. https://doi.org/10.3109/ 09513590.2015 .1062860 .

26. de Morais TL, Giribela C, Nisenbaum MG, et al. Effects of a contraceptive containing drospirenone and ethinylestradiol on blood pressure, metabolic profile and neurohumoral axis in hypertensive women at reproductive age. Eur J Obstet Gynecol Reprod Biol. 2014;182:113-7. https://doi.org/10.1016/j.ejogrb. 2014.09.006

27. Committee on Practice Bulletins-Gynecology, LongActing Reversible Contraception Work Group. Practice Bulletin No. 186: long-acting reversible contraception: implants and intrauterine devices. Obstet Gynecol. 
2017;130(5):e251-69. https://doi.org/10.1097/AOG. 0000000000002400.

28. Trussell J. Contraceptive failure in the United States. Contraception. 2011;83(5):397-404. https://doi.org/ 10.1016/j.contraception.2011.01.021.

29. Espey E, Ogburn T. Long-acting reversible contraceptives: intrauterine devices and the contraceptive implant. Obstet Gynecol. 2011;117(3):705-19. https:// doi.org/10.1097/AOG.0b013e31820ce2fo.

30. Croxatto HB. Mechanisms that explain the contraceptive action of progestin implants for women. Contraception. 2002;65(1):21-7. https://doi.org/10.1016/ s0010-7824(01)00294-3.

31. Black A, Guilbert E, Costescu D, Dunn S, Fisher W, Kives S, et al. Canadian contraception consensus (part 3 of 4): chapter 7-intrauterine contraception. J Obstet Gynaecol Can. 2016;38(2):182-222. https://doi.org/ 10.1016/j.jogc.2015.12.002.

32. Black A, Ad-Hoc Dmpa Update Committee, Special Contributors. Canadian contraception consensusupdate on depot Medroxyprogesterone acetate (dmpa). J Obstet Gynaecol Can. 2006;28(4):305-8. https://doi.org/10.1016/S1701-2163(16)32125-9.

33. Bastianelli C, Farris M, Rosato E, Brosens I, Benagiano G. Pharmacodynamics of combined estrogenprogestin oral contraceptives 3. Inhibition of ovulation. Expert Rev Clin Pharmacol. 2018;11(11):108598. https://doi.org/10.1080/17512433.2018. 1536544

34. Ortiz ME, Croxatto HB. Copper-T intrauterine device and levonorgestrel intrauterine system: biological bases of their mechanism of action. Contraception. 2007;75(6 Suppl):S16-30. https://doi.org/10.1016/j. contraception.2007.01.020.

35. Gray B, Floyd S, James AH. Contraceptive management for women who are at high risk of thrombosis. Clin Obstet Gynecol. 2018;61(2):243-9. https://doi.org/ 10.1097/GRF.0000000000000356.

36. Cleland K, Zhu H, Goldstuck N, Cheng L, Trussell J. The efficacy of intrauterine devices for emergency contraception: a systematic review of 35 years of experience. Hum Reprod. 2012;27(7):1994-2000. https://doi.org/ 10.1093/humrep/des140.

37. Bahamondes L, Valeria Bahamondes M, Shulman LP. Non-contraceptive benefits of hormonal and intrauterine reversible contraceptive methods. Hum Reprod Update. 2015;21(5):640-51. https://doi.org/10.1093/ humupd/dmv023.

38. Soini T, Hurskainen R, Grénman S, Mäenpää J, Paavonen J, Pukkala E. Cancer risk in women using the levonorgestrel-releasing intrauterine system in Finland. Obstet Gynecol. 2014;124(2 Pt 1):292-9. https://doi. org/10.1097/AOG.0000000000000356.

39. Jatlaoui TC, Riley HEM, Curtis KM. The safety of intrauterine devices among young women: a systematic review. Contraception. 2017;95(1):17-39. https://doi org/10.1016/j.contraception.2016.10.006.

40. Scavuzzi A, Souza ASR, Costa AAR, Amorim MMR. Misoprostol prior to inserting an intrauterine device in nulligravidas: a randomized clinical trial. Hum Reprod. 2013;28(8):2118-25. https://doi.org/10.1093/ humrep/det 240 .

41. Andrade AT, Pizarro Orchard E. Quantitative studies on menstrual blood loss in IUD users. Contraception. 1987;36(1):129-44. https://doi.org/10.1016/00107824(87)90065-5.

42. Heinemann K, Reed S, Moehner S, Minh TD. Comparative contraceptive effectiveness of levonorgestrelreleasing and copper intrauterine devices: the European Active Surveillance Study for Intrauterine Devices. Contraception. 2015;91(4):280-3. https://doi.org/10. 1016/j.contraception.2015.01.011.

43. Sun X, Xue M, Deng X, Lin Y, Tan Y, Wei X. Clinical characteristic and intraoperative findings of uterine perforation patients in using of intrauterine devices (IUDs). Gynecol Surg. 2018;15(1):3. https://doi.org/ 10.1186/s10397-017-1032-2.

44. Baddour LM, Wilson WR, Bayer AS, Fowler VG Jr, Tleyjeh IM, Rybak MJ, et al. Infective endocarditis in adults: diagnosis, antimicrobial therapy, and management of complications: a scientific statement for healthcare professionals from the American Heart Association. Circulation. 2015;132(15):1435-86. https://doi.org/10.1161/CIR.0000000000000296.

45. Meyerowitz EA, Prager S, Stout K, Roxby A. Endocarditis following IUD insertion in a patient with tetralogy of Fallot. BMJ Case Rep. 2019;12(2). https://doi.org/ 10.1136/bcr-2018-227962.

46. Han L, Taub R, Jensen JT. Cervical mucus and contraception: what we know and what we don't. Contraception. 2017;96(5):310-21. https://doi.org/10.1016/ j.contraception.2017.07.168.

47. Mestad R, Secura G, Allsworth JE, Madden T, Zhao Q, Peipert JF. Acceptance of long-acting reversible contraceptive methods by adolescent participants in the Contraceptive CHOICE Project. Contraception. 2011;84(5):493-8. https://doi.org/10.1016/j. contraception.2011.03.001.

48. Blumenthal PD, Gemzell-Danielsson K, MarintchevaPetrova M. Tolerability and clinical safety of Implanon. Eur J Contracept Reprod Health Care. 2008;13(Suppl 1):29-36. https://doi.org/10.1080/ 13625180801960012.

49. Mansour D, Korver T, Marintcheva-Petrova M, Fraser IS. The effects of Implanon on menstrual bleeding patterns. Eur J Contracept Reprod Health Care. 2008;13(Suppl 1):13-28. https://doi.org/10.1080/ 13625180801959931.

50. Vieira CS, de Nadai MN, de Melo Pereira do Carmo LS, et al. Timing of postpartum etonogestrel-releasing implant insertion and bleeding patterns, weight change, 12-month continuation and satisfaction rates: a randomized controlled trial. Contraception. 2019;100(4):258-63. https://doi.org/10.1016/j. contraception.2019.05.007.

51. ACOG Practice Bulletin No. 206: use of hormonal contraception in women with coexisting medical 
conditions. Obstet Gynecol. 2019;133(2):e128-50. https://doi.org/10.1097/AOG.0000000000003072.

52. Chapman L, Magos A. Female sterilization. Expert Rev Med Devices. 2008;5(4):525-37. https://doi.org/10. 1586/17434440.5.4.525.

53. Pati S, Cullins V. Female sterilization. Evidence. Obstet Gynecol Clin N Am. 2000;27(4):859-99. https://doi. org/10.1016/s0889-8545(05)70175-3.

54. Creinin MD, Zite N. Female tubal sterilization: the time has come to routinely consider removal. Obstet Gynecol. 2014;124(3):596-9. https://doi.org/10. 1097/AOG.0000000000000422.

55. Gizzo S, Bertocco A, Saccardi C, di Gangi S, Litta PS, D'antona D, et al. Female sterilization: update on clinical efficacy, side effects and contraindications. Minim Invasive Ther Allied Technol. 2014;23(5):26170. https://doi.org/10.3109/13645706.2014.901975.

56. Kollar LM, Biro FM, Boehner CW, Rosenthal SL. Barriers to adolescent adherence to contraception. Knowledge Of depo provera timing. J Pediatr Adolesc Gynecol. 2000;13(2):92. https://doi.org/10.1016/ s1083-3188(00)00023-1.

57. Jirakittidul P, Somyaprasert C, Angsuwathana S. Prevalence of documented excessive weight gain among adolescent girls and young women using depot medroxyprogesterone acetate. J Clin Med Res. 2019;11(5):326-31. https://doi.org/10.14740/ jocmr3792.

58. Lopez LM, Ramesh S, Chen M, Edelman A, Otterness C, Trussell J, et al. Progestin-only contraceptives: effects on weight. Cochrane Database Syst Rev.

2016;8:CD008815. https://doi.org/10.1002/

14651858.CD008815.pub4.

59. Oduyebo T, Zapata LB, Boutot ME, et al. Factors associated with postpartum use of long-acting reversible contraception. Am J Obstet Gynecol. 2019;221(1):43.e1-43.e11. https://doi.org/10.1016/j. ajog.2019.03.005.

60. Dilshad H, Ismail R, Naveed S, Usmanghani K, Alam MT, Sarwar G. Effect of hormonal contraceptives on serum lipids: a prospective study. Pak J Pharm Sci. 2016;29(4 Suppl):1379-82.

61. Graham S, Fraser IS. The progestogen-only mini-pill Contraception. 1982;26(4):373-88. https://doi.org/ 10.1016/0010-7824(82)90104-4.
62. Canobbio MM. Contraception for the adolescent and young adult with congenital heart disease. Nurs Clin North Am. 2004;39(4):769-85. https://doi.org/10. 1016/j.cnur.2004.08.001.

63. Dragoman MV. The combined oral contraceptive pill recent developments, risks and benefits. Best Pract Res Clin Obstet Gynaecol. 2014;28(6):825-34. https:// doi.org/10.1016/j.bpobgyn.2014.06.003.

64. Sitruk-Ware R. Hormonal contraception and thrombosis. Fertil Steril. 2016;106(6):1289-94. https://doi. org/10.1016/j.fertnstert.2016.08.039.

65. Practice Committee of the American Society for Reproductive Medicine. Electronic address:

ASRM@asrm.org, Practice Committee of the American Society for Reproductive Medicine. Combined hormonal contraception and the risk of venous thromboembolism: a guideline. Fertil Steril. 2017;107(1):4351. https://doi.org/10.1016/j.fertnstert.2016.09.027.

66. Machado RB, Gandolpho AC, Santana N, Bocardo RC, Palandri N, Machado RM. Contraception for women with heart disease: an update. Minerva Ginecol. 2017;(3). https://doi.org/10.23736/S0026-4784.17. 04041-2.

67. Plu-Bureau G, Maitrot-Mantelet L, Hugon-Rodin J, Canonico M. Hormonal contraceptives and venous thromboembolism: an epidemiological update. Best Pract Res Clin Endocrinol Metab. 2013;27(1):25-34. https://doi.org/10.1016/j.beem.2012.11.002.

68. Lee JK, Schwarz EB. The safety of available and emerging options for emergency contraception. Expert Opin Drug Saf. 2017;16(10):1163-71. https://doi.org/10. 1080/14740338.2017.1354985.

69. Pieh Holder KL. Contraception and breastfeeding. Clin Obstet Gynecol. 2015;58(4):928-35. https://doi.org/ 10.1097/GRF.0000000000000157.

\section{Publisher's Note}

Springer Nature remains neutral with regard to jurisdictional claims in published maps and institutional affiliations. 